\title{
ANALIZA STRAT WODY W WODOCIĄGU MIASTA JASŁA
}

\begin{abstract}
Analiza strat wody powinna być podstawą do podejmowania działań modernizacyjnych w celu ograniczenia kosztów związanych z produkcją wody i jej dystrybucja. W pracy przedstawiono analizę zużycia i strat wody w wodociągu w mieście Jasło wykonaną na podstawie danych uzyskanych z Głównego Urzędu Statystycznego oraz Jasielskiego Związku Komunalnego Sp. z o.o. W wyniku badań stwierdzono trend prawie 15 procentowego spadku zużycia wody przez mieszkańców i podmioty gospodarcze. Podczas normalnej eksploatacji sieci wodociągowej w latach 2008-2012 dokonano bilansu produkcji i sprzedaży wody wodociągowej. Ustalono podstawowe wskaźniki strat wody oraz odniesiono je do zaproponowanych wskaźników przez The International Water Association. (IWA). Wyznaczono następujące wskaźniki start wody: procentowy (WS), jednostkowy start rzeczywistych (RLB), objętości wody niedochodowej (MRWB), start nieuniknionych (UARL), infrastrukturalny indeks wycieków (ILI). Przeanalizowane wskaźniki są porównywalne do wartości, które zostały uzyskane w innych systemach zbiorowego zaopatrzenia w wodę w Polsce. Dokonano analizy awaryjności sieci wodociągowej pod kątem wpływu na straty wody. Uzyskane wartości jednostkowych intensywności uszkodzeń na poszczególnych rodzajach sieci wodociągowej wskazują na mało znaczący wpływ awarii na straty wody.
\end{abstract}

Słowa kluczowe: system zaopatrzenia w wodę, straty wody, awarie wodociągowe

\section{Wstęp}

Jasło - miasto położone w południowo-wschodniej części Polski w województwie podkarpackim, $50 \mathrm{~km}$ od granicy ze Słowacją, w dolinie rzek: Wisłoki, Ropy i Jasiołki. Znajduje się na wysokości od 225 do 380 m. n. p. m na obszarze dołów jasielsko-sanockich w rejonie występowania złóż ropy naftowej

\footnotetext{
${ }^{1}$ Autor do korespondencji: Janusz Rak, Politechnika Rzeszowska, al. Powstańców Warszawy 6, 35-959 Rzeszów, tel.: 1786514 49, rakjan@prz.edu.pl.

2 Łukasz Sypień, Politechnika Rzeszowska, al. Powstańców Warszawy 6, 35-959 Rzeszów.
} 
i gazu ziemnego. Miasto zajmuje powierzchnię $36,52 \mathrm{~km}^{2}$ o liczbie mieszkańców 37071 (dane z 2012 r.) [10].

W województwie podkarpackim Jasło jest jednym ze znaczących ośrodków przemysłowych i gospodarczych. W gminie funkcjonuje kilka dużych przedsiębiorstw m.in. Rafineria „Jasło” S.A., Zakłady Tworzyw Sztucznych „Gamrat” S.A., PNiG Jasło Sp.z.o.o, Huta Szkła Sp.z.o.o w Jaśle. Miasto cechuje dobrze rozwinięta sieć handlowa i usługowa w liczbie ponad 3,2 tysięcy podmiotów gospodarczych.

W 1956 roku na rzece Wisłoce rozpoczęto budowę ujęcia wody zlokalizowanego w miejscowości Żółków. Wodę pobierano w istniejącym żwirowisku za pomocą sączków ułożonych równolegle do brzegów rzeki, skąd kierowano ją do studni zbiorczej, a następnie na filtry pośpieszne. Obecnie uzdatnianie wody oparte jest o wysokoefektywny proces koagulacji oparty o technologię ACTiFLO i filtry pospieszne dwuwarstwowe. Wydajność nominalna ZUzW wynosi $17280 \mathrm{~m}^{3} / \mathrm{d}$. W sytuacjach kryzysowych można wykorzystywać ujęcie wód podziemnych o wydajności $350 \mathrm{~m}^{3} / \mathrm{d}$. Sieć wodociągowa liczy $198 \mathrm{~km}$, a dystrybucję wody zapewnia 5 pompowni strefowych.

Celem pracy jest ocena start wody w sieci wodociągowej miasta Jasła. Porównano obliczone wartości wskaźników charakteryzujących starty wody $\mathrm{z}$ danymi IWA, AWWA oraz WBI. Wykonana analiza awaryjności sieci wodociągowej ma pokazać jej wpływ na straty wody.

\section{Analiza zużycia wody w Jaśle}

W tab. 1 przedstawiono ilość wody wtłoczonej do sieci, wodę sprzedaną dla gospodarstw domowych, dla jednostek produkcyjnych oraz dla pozostałych jednostek, zużycie wody na cele własne oraz straty.

Tabela 1. Zestawienie bilansu produkcji wody w latach 2008-2012

Table1. Summary of the water balance production in years 2008-2012

\begin{tabular}{|l|c|c|c|c|c|}
\hline Rok & $\begin{array}{c}\text { Woda wtloczo- } \\
\text { na do sieci } \\
\text { Vwtl }\left[\mathbf{m}^{\mathbf{3}} / \mathbf{r o k}\right]\end{array}$ & $\begin{array}{c}\text { Woda sprze- } \\
\text { dana Vsp } \\
{\left[\mathbf{m}^{3} / \mathbf{r o k}\right]}\end{array}$ & $\begin{array}{c}\text { Woda sprzeda- } \\
\text { na gospod. } \\
\text { domowym } \\
\text { Vspgd }\end{array}$ & $\begin{array}{c}\text { Zużycie wody } \\
\text { na cele wasne } \\
\text { Vwtl }\left[\mathbf{m}^{3} / \mathbf{r o k}\right]\end{array}$ & $\begin{array}{c}\text { Straty wody } \\
\text { Vstr } \\
{\left[\mathbf{m}^{3} / \mathbf{r o k}\right]}\end{array}$ \\
\hline $\mathbf{2 0 0 8}$ & 2374673,10 & 1919308,90 & 1020776,20 & 20365,00 & 434999,20 \\
\hline $\mathbf{2 0 0 9}$ & 2338145,20 & 1899697,18 & 1039756,80 & 28087,00 & 410361,02 \\
\hline $\mathbf{2 0 1 0}$ & 2213624,00 & 1736447,86 & 1024289,80 & 51773,00 & 425403,14 \\
\hline $\mathbf{2 0 1 1}$ & 2106264,00 & 1671865,56 & 1014632,20 & 71563,00 & 362835,44 \\
\hline $\mathbf{2 0 1 2}$ & 2058472,00 & 1622534,16 & 1011415,50 & 69755,00 & 366182,84 \\
\hline
\end{tabular}


Analizując tabelę 1 można jednoznacznie stwierdzić, że podobnie tak jak w innych miastach Polski zużycie wody przez mieszkańców Jasła systematycznie spada. Na przestrzeni 5 lat ilość wody wtłoczonej do sieci zmalała o $13,32 \%$. Od 2008 roku z ponad 2374,67 tyś $\mathrm{m}^{3}$ zapotrzebowanie na wodę spadło do nieco ponad 2058, 47 tyś $\mathrm{m}^{3} \mathrm{w} 2012$ roku.

$\mathrm{W}$ tab. 2 zestawiono ilość wody sprzedanej z podziałem na wodę sprzedaną gospodarstwom domowym, na cele produkcyjne oraz na pozostałe cele.

Tabela 2. Zestawienie bilansu wody sprzedanej w latach 2008-2012

Table 2. Summary of water sold in years 2008-2012

\begin{tabular}{|c|c|c|c|c|}
\hline Rok & $\begin{array}{c}\text { Razem } \\
{\left[\mathbf{m}^{\mathbf{3}} / \mathbf{r o k}\right]}\end{array}$ & $\begin{array}{c}\text { Woda sprzedana } \\
\text { gospodarstwom } \\
\text { domowym }\end{array}$ & $\begin{array}{c}\text { Na cele produkcyj- } \\
\text { ne }\left[\mathbf{m}^{\mathbf{3}} / \mathbf{r o k}\right]\end{array}$ & $\begin{array}{c}\text { Pozostałe cele } \\
{\left[\mathbf{m}^{\mathbf{3}} / \mathbf{r o k}\right]}\end{array}$ \\
\hline $\mathbf{2 0 0 8}$ & 1919308,90 & 1020776,20 & 561894,00 & 336638,70 \\
\hline $\mathbf{2 0 0 9}$ & 1899697,18 & 1039756,80 & 521600,00 & 338340,38 \\
\hline $\mathbf{2 0 1 0}$ & 1736447,86 & 1024289,80 & 381434,00 & 330724,06 \\
\hline $\mathbf{2 0 1 1}$ & 1671865,56 & 1014632,20 & 324542,80 & 332690,56 \\
\hline $\mathbf{2 0 1 2}$ & 1622534,16 & 1011415,50 & 305825,30 & 305293,36 \\
\hline
\end{tabular}

$\mathrm{Z}$ analizy tab. 2 wynika również, że systematycznie od 2008 roku maleje ilość wody sprzedanej na cele produkcyjne, a od 2009 roku nieznacznie dla gospodarstw domowych.

\section{Ogólna charakterystyka strat wody}

Obecnie na całym świecie jednym z podstawowych problemów eksploatacyjnych wodociągów są straty wody [1]. Faktem jest, że niekiedy stanowią one bardzo wysoki procent wody wttaczanej do sieci. Analiza strat wody powinna być podstawą do podejmowania działań modernizacyjnych i naprawczych w celu ograniczenia kosztów związanych z produkcją wody i jej dystrybucją [5]. Wycieki niezmiennie towarzyszą eksploatacji systemów zaopatrzenia w wodę.

Całkowite straty wody stanowią sumę strat rzeczywistych i pozornych oraz wody zużywanej na własne potrzeby systemu wodociągowo-kanalizacyjnego [2]. Jedną z przyczyn powstania rzeczywistych strat wody są przecieki zarówno z sieci przewodów i armatury jak i z nieszczelnych instalacji wewnętrznych (poniżej progu rozruchu wodomierzy), oraz przelewy wody ze zbiorników wyrównawczych, a także nasilające się w ostatnim czasie jej kradzieże. Przecieki powstają na skutek uszkodzeń złączy, rurociągów i kształtek. Według niemieckich badań stanowią one od $80-100 \%$ rzeczywistych strat wody z zewnętrznej sieci wodociągowej [1]. Pozorne straty wody nie stanowią natomiast faktycz- 
nego jej wycieku z systemu. Wynikają one jedynie z niedokładności i niejednoczesności dostawy i zużycia wody [7].

Podstawowym elementem oceny efektywności pracy, oraz stanu technicznego systemu wodociągu $\mathrm{w}$ aspekcie zużycia i strat wody jest jej prawidłowe zbilansowanie. Niejednokrotnie przedsiębiorstwa wodociągowe nie dokonują takiego bilansu, a wielkość strat jest nie raz świadomie ukrywana lub zaniżana. Zdarza się, że całkowita objętość wody nie jest dokładnie mierzona przez przedsiębiorstwo, aby nie wykazywać rzeczywistych strat występujących w sieci. Ponad to zawyżane są wartości wody zużywanej na potrzeby własne w celu zaniżenia wykazywanego procentowego wskaźnika strat wody. Skala tego problemu uwidoczniła się w Polsce dopiero w okresie gospodarki rynkowej. Przemiany społeczno-gospodarcze, jakie miały miejsce na początku lat 90tych spowodowały, że przedsiębiorstwa zaczęły dostrzegać powagę problemu strat wody. Transformacja ta była przyczyną urynkowienia cen wody, a zagadnienia związane z jej stratami stały się głównym problemem kadry zarządzającej przedsiębiorstwami wodociągowymi. Przełom XX i XXI wieku przyniósł znaczący spadek zużycia wody wodociągowej [4].

\section{Analiza strat wody w wodociągu Jasła}

Zestawienie podstawowych danych dotyczących obliczeń strat wody wg International Water Association (IWA) obejmuje następujące parametry [9]:

- Woda wtłoczona do sieci - Vwt1

- Zużycie własne wody - Vwł

- Woda sprzedana -Vsp

- Straty wody - Vstr

- Długość sieci magistralnej - M (w Jaśle nie występuje - gdyż do rurociągu magistralnego nie mogą być bezpośrednio podłączeni odbiorcy wody)

- Długość sieci rozdzielczej - R

- Całkowita długość sieci wodociągowej-M+R

- Długość podłączeń wodociągowych - PW

- Liczba podłączeń wodociągowych - Lpw

$\mathrm{W}$ tab. 3. zestawiono dhugości poszczególnych rodzajów sieci wodociągowej, oraz liczbę przyłączy.

Do wskaźników pozwalających na wyznaczenie prawidłowej i wiarygodnej oceny strat wody należą:

- Procentowy wskaźnik strat wody

Wskaźnik ten pozwala na określenie udziału strat wody (Vstr) w stosunku do objętości wody wtłoczonej (Vwtł) do sieci wodociągowej. Wyznaczany z zależności: 


$$
\mathrm{WS}=\frac{\mathrm{Vstr}}{\mathrm{VwtI}} \cdot 100 \%
$$

- Wskaźnik jednostkowy strat rzeczywistych - RLB

Inaczej zwany indeksem strat rzeczywistych, zakwalifikowany do wskaźników operacyjnych przez International Water Association (IWA) [6]. Opisuje on ilość rzeczywistych strat wody w zależności od liczby przyłączy wodociągowych, co zwiększa dokładność oceny efektywnej pracy wodociągu. Faktem jest, że awaryjność sieci wzrasta wraz z liczbą obecnej na sieci armatury, która z pewnością występuje najobficiej na przyłączach wodociągowych. Możliwe są dwie wersje tego wskaźnika:

$$
\mathrm{RLB}_{1}=\frac{\mathrm{Vstr}}{(\mathrm{M}+\mathrm{R}) \cdot 365} \mathrm{~m}^{3} /(\mathrm{km} \cdot \mathrm{d})
$$

Stosowanie tego wskaźnika zaleca się, gdy liczba podłączeń wodociągowych przypadających na kilometr sieci wodociągowej $(\mathrm{M}+\mathrm{R})$ jest mniejsza od 20 .

$$
\mathrm{RLB}_{2}=\frac{\mathrm{Vstr} \cdot 1000}{\mathrm{Lpw} \cdot 365}\left[\mathrm{dm}^{3} /(\text { dpodłączenie wodociągowe })\right]
$$

Stosowanie tego wskaźnika zaleca się, gdy liczba podłączeń wodociągowych przypadających na kilometr sieci wodociągowej $(\mathrm{M}+\mathrm{R})$ wynosi, co najmniej 20.

- Wskaźnik objętości wody niedochodowej - NRWB

Wskaźnik ten określa objętość wody niesprzedanej, wyznaczonej z różnicy pomiędzy objętością wody wyprodukowanej a objętością wody sprzedanej. Pozwala on na uniknięcie przekłamań podczas analiz porównawczych powstałych na skutek zawyżania objętości wody zużywanej na potrzeby własne, przez przedsiębiorstwa wodociągowe $\mathrm{w}$ celu zaniżenia procentowego wskaźnika strat wody. Wyznaczany z zależności:

$$
\mathrm{NRWB}=\frac{\mathrm{Vwt} \nmid-\mathrm{Vsp}}{\text { Vwtł }} \cdot 100[\%]
$$

- Wskaźnik strat nieuniknionych - UARL

Biorąc pod uwagę skomplikowany system dystrybucji wody, wynikający z mnogości elementów tworzących jego strukturę, należy zdawać sobie sprawę $\mathrm{z}$ tego, że w każdym wodociągu będą występować pewne nieuniknione straty 
wody. Ich wielkość wyznaczana jest właśnie przez wskaźnik UARL. Straty nieuniknione tolerowane są przez przedsiębiorstwa wodociągowe, gdyż wycieki o wielkości poniżej $0,5 \mathrm{~m}^{3} / \mathrm{h}$ są bardzo trudne do wykrycia i zlokalizowania. Do obliczenia tego wskaźnika potrzebna jest znajomość średniego ciśnienia wody panującego $\mathrm{w}$ sieci, długości zarówno przewodów rozdzielczych jak i magistralnych, oraz długość i liczba przyłączy. Objętość roczna wody wodociągowej w formie strat nieuniknionych określana jest na podstawie składników [6]:

- wycieki nieuniknione na przewodach sieci magistralnej i rozdzielczej, przyjmuje się $18 \mathrm{dm}^{3} / \mathrm{km} \cdot \mathrm{d} \cdot 1 \mathrm{~m} \mathrm{H}_{2} \mathrm{O}$ ciśnienia,

- wycieki nieuniknione na przewodach podłączeń wodociągowych, przyjmuje się $25 \mathrm{dm}^{3} / 1 \mathrm{~m}$ podłączen $\cdot \mathrm{d} \cdot 1 \mathrm{~m} \mathrm{H}_{2} \mathrm{O}$ ciśnienia,

- wycieki nieuniknione związane z liczbą podłączeń wodociągowych, przyjmuje się $0,8 \mathrm{dm}^{3} / 1$ podłączenie $\cdot \mathrm{d} \cdot 1 \mathrm{~m} \mathrm{H}_{2} \mathrm{O}$ ciśnienia,

Zależność ta jest wyrażona wzorem:

$\mathrm{UARL}=[18 \cdot(\mathrm{M}+\mathrm{R})+25 \cdot \mathrm{PW}+0,8 \cdot \mathrm{Lpw}] \cdot 0,365 \cdot \mathrm{p} \quad\left[\mathrm{m}^{3} / \mathrm{rok}\right]$

gdzie: $\quad \mathrm{M}-$ długość sieci magistralnej, $[\mathrm{km}]$

$\mathrm{R}$ - długość sieci rozdzielczej, [km]

PW - długość podłączeń wodociągowych, [km]

Lpw - liczba podłączeń wodociągowych,

$\mathrm{p}$ - średnie ciśnienie w rozpatrywanej strefie pomiarowej, $\left[\mathrm{mH}_{2} \mathrm{O}\right]$

$\mathrm{p}=35 \mathrm{~m} \mathrm{H}_{2} \mathrm{O}$

0,365 - współczynnik przeliczeniowy na rok i $\mathrm{m}^{3}$

- Infrastrukturalny indeks wycieków - ILI

Jest to wielkość bezwymiarowa zdefiniowana, jako stosunek objętości rzeczywistych strat wody do strat nieuniknionych. Indeks ten pozwala zobrazować krotność rzeczywistych strat wody w stosunku do minimalnego poziomu wycieków, jaki może być osiągnięty przy dobrze działającym i utrzymywanym w dobrej kondycji systemie. Współczynnik ten uwzględnia aktualny stan sieci wodociągowej oraz opisuje straty w sieci w bardziej wymierny sposób niż dotychczas stosowany wskaźnik procentowy [6]. Pozwala on pośrednio ocenić stan techniczny sieci wodociągowej, wyznaczany z zależności:

$$
\mathrm{ILI}=\frac{\mathrm{V}_{\text {str }}}{\mathrm{UARL}}[-]
$$

gdzie: $V_{\text {str }}$ - roczna objętość wody niesprzedanej, $\mathrm{m}^{3} /$ rok

UARL - wskaźnik strat nieuniknionych 
Tabela 3. Zestawienie długości sieci wodociągowej w Jaśle

Table 3. Summary of the water supply system length in Jasło

\begin{tabular}{|c|c|c|c|c|}
\hline Rok & $\begin{array}{c}\text { Długość sieci } \\
\text { rozdzielczej R } \\
\text { [km] }\end{array}$ & $\begin{array}{c}\text { Długość podłą- } \\
\text { czeń wodocią- } \\
\text { gowych PW } \\
\text { [km] }\end{array}$ & Razem L [km] & Lpw \\
\hline $\mathbf{2 0 0 8}$ & 116,9 & 60,0 & 176,9 & 2840 \\
\hline $\mathbf{2 0 0 9}$ & 127,8 & 60,2 & 188,0 & 2890 \\
\hline $\mathbf{2 0 1 0}$ & 132,4 & 60,5 & 193,1 & 3120 \\
\hline $\mathbf{2 0 1 1}$ & 133,9 & 60,8 & 194,7 & 3330 \\
\hline $\mathbf{2 0 1 2}$ & 138,4 & 60,9 & 199,3 & 3395 \\
\hline
\end{tabular}

W tab. 4 zestawiono obliczenia wskaźników strat wody dla analizowanego systemu.

Tabela 4. Zestawienie wskaźników strat wody w latach 2008-2012

Table 4. The list of water loss indicators in years 2008-2012

\begin{tabular}{|c|c|c|c|c|c|c|}
\hline Rok & $\begin{array}{c}\text { WSW } \\
{[\%]}\end{array}$ & $\begin{array}{c}\mathbf{N R W B} \\
{[\%]}\end{array}$ & $\begin{array}{c}\mathbf{R} \mathbf{R B}_{\mathbf{1}} \\
{\left[\mathbf{m}^{\mathbf{3}} /(\mathbf{k m} \cdot \mathbf{d})\right]}\end{array}$ & $\begin{array}{c}\mathbf{R L B}_{\mathbf{2}} \\
{\left[\mathbf{d m}^{\mathbf{3}} /(\mathbf{d P W}]\right.}\end{array}$ & $\begin{array}{c}\text { UARL } \\
{\left[\mathbf{m}^{\mathbf{3}} / \mathbf{r o k}\right]}\end{array}$ & ILI \\
\hline $\mathbf{2 0 0 8}$ & 18,3 & 19,2 & 10,2 & 419,6 & 75068,5 & 5,8 \\
\hline $\mathbf{2 0 0 9}$ & 17,6 & 18,8 & 8,8 & 389,0 & 78085,9 & 5,3 \\
\hline $\mathbf{2 0 1 0}$ & 19,2 & 21,6 & 8,8 & 373,6 & 81494,3 & 5,2 \\
\hline $\mathbf{2 0 1 1}$ & 17,2 & 20,6 & 7,4 & 298,5 & 83985,4 & 4,3 \\
\hline $\mathbf{2 0 1 2}$ & 17,8 & 21,2 & 7,2 & 334,0 & 81688,5 & 4,5 \\
\hline
\end{tabular}

W tab. 5 zestawiono kategorie wartości wskaźnika ILI [6].

Infrastrukturalny wskaźnik wycieków ILI, który przyjmuje wartości od 5,8- 4,3 wg WBI Banding System dla krajów rozwiniętych oceniany jest jako słaby, natomiast dla krajów rozwijających się jako dobry. Według Amerykańskiego Stowarzyszenia Wodnego (AWWA) stan sieci wodociągowej oceniany jest jako dobry dla wartości niższych niż 5,0 lub słaby dla wartości większych niż 5,0. Bardzo rygorystyczne kryteria Międzynarodowego Stowarzyszenia Wodnego (IWA) odnoszące się do krajów wysokorozwiniętych wskazują na stan niedopuszczalny sieci. Przeciętne wartości infrastrukturalnego indeksu wycieków ILI w miastach Polski wynoszą od 3,16 do 16,62 [4], z czego można wywnioskować, że Jasło jest na dość zadowalającej poz-ycji. Spadek w ostatnich latach wartości wskaźnika ILI, świadczy o skuteczności przyjętej strategii ograniczania przecieków wody w wodociągu Jasło. 
Tabela 5. Kategorie wartości współczynnika ILI

Table 5. Coefficient values of ILI

\begin{tabular}{|c|c|c|c|c|}
\hline \multirow{2}{*}{$\begin{array}{c}\text { Zakres oraz } \\
\text { kategorie ILI } \\
\text { wg IWA }\end{array}$} & \multirow{2}{*}{$\begin{array}{l}\text { Kategorie } \\
\text { ILI }\end{array}$} & \multicolumn{2}{|c|}{$\begin{array}{c}\text { Zakres ILI wg WBI Banding } \\
\text { System }\end{array}$} & \multirow{2}{*}{$\begin{array}{l}\text { Zakres } \\
\text { ILI wg } \\
\text { AWWA }\end{array}$} \\
\hline & & $\begin{array}{c}\text { Kraje rozwi- } \\
\text { jające się }\end{array}$ & $\begin{array}{c}\text { Kraje } \\
\text { rozwinięte }\end{array}$ & \\
\hline $\begin{array}{c}\text { ILI } \leq 1,5 \text { - stan } \\
\text { bardzo dobry }\end{array}$ & \multirow{2}{*}{$\begin{array}{l}\text { stan bardzo } \\
\text { dobry }\end{array}$} & \multirow{2}{*}{$\mathrm{ILI} \leq 4,0$} & \multirow{2}{*}{$\mathrm{ILI} \leq 2,0$} & \multirow{2}{*}{$\mathrm{ILI} \leq 3,0$} \\
\hline $\begin{array}{l}1,5<\text { ILI } \leq 2 \\
- \text { stan dobry }\end{array}$ & & & & \\
\hline $\begin{array}{l}1,5<\text { ILI } \leq 2 \\
\text { - stan średni }\end{array}$ & stan dobry & $4,0<\mathrm{ILI} \leq 8$ & $\begin{array}{c}2,0<\text { ILI } \leq \\
4,0\end{array}$ & $\begin{array}{c}3,0<\text { ILI } \leq \\
5,0\end{array}$ \\
\hline $\begin{array}{c}2,5<\text { ILI } \leq 3,0 \\
\text { - stan slaby }\end{array}$ & \multirow{2}{*}{ stan słaby } & \multirow{2}{*}{$\begin{array}{c}8,0<\mathrm{ILI} \leq \\
16,0\end{array}$} & \multirow{2}{*}{$\begin{array}{c}4,0<\mathrm{ILI} \leq \\
\quad 8,0\end{array}$} & \multirow{2}{*}{$\begin{array}{c}5,0<\mathrm{ILI} \leq \\
8,0\end{array}$} \\
\hline $\begin{array}{c}\text { 3,0 }<\text { ILI } \leq 3,5 \\
- \text { stan bardzo } \\
\text { słaby }\end{array}$ & & & & \\
\hline $\begin{array}{l}\text { ILI > 3,5 - stan } \\
\text { niedopuszczalny }\end{array}$ & $\begin{array}{c}\text { stan } \\
\text { niedopusz- } \\
\text { - czalny }\end{array}$ & $\mathrm{ILI}>16,0$ & ILI $>8,0$ & ILI $>8,0$ \\
\hline
\end{tabular}

\section{Obliczenie jednostkowych wskaźników strat wody w anali- zowanym systemie}

Dobrą charakterystyką eksploatacyjną analizy strat wody są jednostkowe wskaźniki [9]:

- Jednostkowa ilość wody wtłoczonej do sieci

$$
\mathrm{q}_{\mathrm{wt}}=\frac{\mathrm{Vwtł} \cdot 1000}{\mathrm{LM} \cdot 365} \quad\left[\mathrm{dm}^{3} /(\cdot \mathrm{d})\right]
$$

- Jednostkowa ilość wody sprzedanej ogółem

$$
\mathrm{q}_{\mathrm{sp}}=\frac{\mathrm{Vsp} \cdot 1000}{\mathrm{LM} \cdot 365} \quad\left[\mathrm{dm}^{3} /(\cdot \mathrm{d})\right]
$$

- Jednostkowa ilość wody sprzedanej gospodarstwom domowym 


$$
\mathrm{q}_{\text {spgd }}=\frac{\operatorname{Vspgd} \cdot 1000}{\mathrm{LM} \cdot 365} \quad\left[\mathrm{dm}^{3} /(\cdot \mathrm{d})\right]
$$

- Jednostkowa ilość strat wody

$$
\mathrm{q}_{\mathrm{str}}=\frac{\mathrm{Vstr} \cdot 1000}{\mathrm{LM} \cdot 365} \quad\left[\mathrm{dm}^{3} /(\cdot \mathrm{d})\right]
$$

- Jednostkowa ilość wody zużytej na potrzeby własne

$$
\mathrm{q}_{\mathrm{w}}=\frac{\mathrm{Vwł} \cdot 1000}{\mathrm{LM} \cdot 365} \quad\left[\mathrm{dm}^{3} /(\cdot \mathrm{d})\right]
$$

- Jednostkowa ilość wody niedochodowej

$$
\mathrm{q}_{\mathrm{nd}}=\frac{(\text { Vwtł }-\mathrm{Vsp}) \cdot 1000}{\mathrm{LM} \cdot 365} \quad\left[\mathrm{dm}^{3} /(\cdot \mathrm{d})\right]
$$

W tab. 6 zestawiono jednostkowe wskaźniki związane ze stratami wody.

Tabela 6. Jednostkowe wskaźniki ilości wody w latach 2008-2012

Table 6. Specific indicators of the water amount in 2008-2012

\begin{tabular}{|c|c|c|c|c|c|}
\hline \multirow{2}{*}{$\begin{array}{c}\text { Jednostkowy wskaźnik ilości } \\
\text { wody }\end{array}$} & \multicolumn{5}{|c|}{ Rok } \\
\cline { 2 - 6 } & $\mathbf{2 0 0 8}$ & $\mathbf{2 0 0 9}$ & $\mathbf{2 0 1 0}$ & $\mathbf{2 0 1 1}$ & $\mathbf{2 0 1 2}$ \\
\hline qwtl & 182,42 & 178,83 & 169,06 & 161,04 & 163,43 \\
\hline qsp & 147,44 & 145,29 & 132,61 & 127,82 & 128,82 \\
\hline qspgd & 78,41 & 79,52 & 78,23 & 77,57 & 80,30 \\
\hline qstr & 33,42 & 31,39 & 32,49 & 27,74 & 29,07 \\
\hline qwı & 1,56 & 2,15 & 3,95 & 5,47 & 5,54 \\
\hline qnd & 34,98 & 33,53 & 36,44 & 33,21 & 34,61 \\
\hline $\begin{array}{c}\text { Liczba mieszkańców korzy- } \\
\text { stających z wodociągu }\end{array}$ & 35665 & 35822 & 35874 & 35834 & 34507 \\
\hline
\end{tabular}

$\mathrm{Z}$ danych zamieszczonych $\mathrm{w}$ tabeli 6 wynika, że jednostkowy wskaźnik wody wtłoczonej do sieci wynosi od 182,42 $\mathrm{dm}^{3} /(\mathrm{Mk} \cdot \mathrm{d})$ w 2008 roku do 161,04 $\mathrm{dm}^{3} /(\mathrm{Mk} \cdot \mathrm{d})$ w $2011 \mathrm{roku}$. Natomiast jednostkowa ilość wody sprzedanej ogółem wynosi od 147,44 $\mathrm{dm}^{3} /(\mathrm{Mk} \cdot \mathrm{d})$ w $2008 \mathrm{roku}$ do 127,82 $\mathrm{dm}^{3} /(\mathrm{Mk} \cdot \mathrm{d})$ w 2011 
roku, co odpowiada średnim wartością sprzedaży wody w Polsce [9]. Dla gospodarstw domowych jednostkowy wskaźnik wynosi ok. $80 \mathrm{dm}^{3} /(\mathrm{Mk} \cdot \mathrm{d})$, co jest wartością nieco niższą niż przeciętne w Polsce. Nieznacznie wyższe wartości w 2012 roku mogą być spowodowane mniejszą liczbą odbiorców wody. Jednostkowy wskaźnik strat wody w badanym okresie wyniósł około $30 \mathrm{dm}^{3} /(\mathrm{Mk} \cdot \mathrm{d})$.

Wyznaczenie jednostkowego wskaźnika obciążenia hydraulicznego sieci wodociągowej $\mathrm{M}+\mathrm{R}$

$$
\mathrm{q}_{\mathrm{o}}=\frac{\text { Vwtł }}{\mathrm{L}_{\mathrm{M}+\mathrm{R}} \cdot 365} \quad\left[\mathrm{~m}^{3} /(\mathrm{k} \cdot \mathrm{d})\right]
$$

Wyznaczenie jednostkowego wskaźnika strat wody w odniesieniu do całej długości sieci wodociągowej

$$
\begin{aligned}
& \mathrm{q}_{\mathrm{strL}}=\frac{\text { Vwtł }}{\mathrm{L} \cdot 365} \quad\left[\mathrm{~m}^{3} /(\mathrm{k} \cdot \mathrm{d})\right] \\
& \mathrm{V}^{\prime}{ }_{\text {str }}=\mathrm{V}_{\mathrm{str}}-\mathrm{UARL} \quad\left[\mathrm{m}^{3} / \mathrm{rok}\right] \\
& \mathrm{q}_{\text {str.L }}^{\prime}=\frac{\mathrm{V}_{\text {str }}^{\prime}}{\mathrm{L} \cdot 365} \quad\left[\mathrm{~m}^{3} /(\mathrm{k} \cdot \mathrm{d})\right]
\end{aligned}
$$

W tab. 7 zestawiono wartości jednostkowych wskaźników obciążeń hydraulicznych sieci wodociągowej.

Tabela 7. Zestawienie wskaźników jednostkowych obciążeń hydraulicznych sieci wodociągowej w Jaśle

Table 7. The list of individual indicators hydraulic loads of water in Jasło

\begin{tabular}{|c|c|c|c|c|}
\hline $\mathbf{R o k}$ & $\begin{array}{c}\mathbf{q} \\
{\left[\mathbf{m}^{\mathbf{3}} /(\mathbf{k m} \cdot \mathbf{d})\right]}\end{array}$ & $\begin{array}{c}\mathbf{q}_{\text {str.L }} \\
{\left[\mathbf{m}^{\mathbf{3}} /(\mathbf{k m} \cdot \mathbf{d})\right]}\end{array}$ & $\begin{array}{c}\mathbf{V}^{\prime}{ }_{\text {str }} \\
{\left[\mathbf{m}^{\mathbf{3}} / \mathbf{r o k}\right]}\end{array}$ & $\mathbf{q}_{\text {str.L }}^{\prime}$ \\
\hline $\mathbf{2 0 0 8}$ & 55,7 & 6,74 & 359930,7 & 5,57 \\
\hline $\mathbf{2 0 0 9}$ & 50,1 & 5,99 & 332275,1 & 4,85 \\
\hline $\mathbf{2 0 1 0}$ & 45,8 & 6,06 & 343908,9 & 4,90 \\
\hline $\mathbf{2 0 1 1}$ & 43,1 & 5,13 & 278850,0 & 3,94 \\
\hline $\mathbf{2 0 1 2}$ & 40,7 & 5,06 & 284494,4 & 3,93 \\
\hline
\end{tabular}

Wartości jednostkowych wskaźników strat wody mieszczą się w przedziale wartości podanych w pracy [3] dotyczących wodociągów krajowych. 


\section{Awaryjność wodociągu Jasto}

Awaryjność sieci wodociągowej można zdefiniować, jako uszkodzenia lub niesprawności przewodów wodociągowych wraz $\mathrm{z}$ uzbrojeniem powodujące częściową lub całkowitą utratę wymaganych własności funkcjonalnych. Zazwyczaj są to brak szczelności i przepustowości oraz uszkodzenia uzbrojenia, uniemożliwiające jego pracę i wymagające naprawy z odcięciem dopływu wody.

Jednym z najistotniejszych wskaźników oceny stanu technicznego sieci i sytuacji eksploatacyjnej danego wodociągu jest awaryjność przewodów. Literatura techniczna określa ten wskaźnik mianem ,intensywności uszkodzeń rurociągów" $(\lambda)$ [3]. Intensywność uszkodzeń sieci wodociągowej oblicza się $\mathrm{w}$ odniesieniu do jednego $\mathrm{km}$ jej długości, oraz jednostki czasu równej jeden rok. Zależność tą wyznacza się ze wzoru:

$$
\lambda=\frac{\mathrm{k}}{\mathrm{L} \cdot \Delta \mathrm{t}} \quad\left[\frac{1}{(\mathrm{~km} \cdot \mathrm{rok})}\right]
$$

gdzie: $\mathrm{k}$ - liczba awarii poszczególnych sieci wodociągowych,

L - długość sieci wodociągowej,

$\Delta \mathrm{t}$ - przyrost czasu, w którym dana liczba awarii miała miejsce równy 1 rok.

W tab. 8 zestawiono liczbę awarii i wskaźniki intensywności uszkodzeń poszczególnych sieci wodociągowych (sieć rozdzielcza oraz podłączenia wodociągowe).

Tabela 8. Zestawienie intensywności uszkodzeń sieci wodociągowej $\lambda[1 /(\mathrm{km} \cdot \mathrm{rok})]$

Table 8 . Summary of the water supply system failure rate $\lambda[1 /(\mathrm{km} \cdot$ year) $]$

\begin{tabular}{|c|c|c|c|c|c|}
\hline \multirow{2}{*}{ Oznaczenia } & \multicolumn{5}{|c|}{ Rok } \\
\hline & 2008 & 2009 & 2010 & 2011 & 2012 \\
\hline Liczba awarii sieci rozdzielczej & 63 & 34 & 37 & 27 & 38 \\
\hline Intensywność uszkodzeń $\lambda_{R}$ & 0,54 & 0,27 & 0,28 & 0,20 & 0,27 \\
\hline $\begin{array}{l}\text { Liczba awarii podlączeń wodociągo- } \\
\text { wych }\end{array}$ & 21 & 20 & 14 & 28 & 18 \\
\hline $\begin{array}{c}\text { Intensywność uszkodzeń podłączeń } \\
\text { wodociągowych } \lambda \mathrm{PW}\end{array}$ & 0,35 & 0,33 & 0,23 & 0,47 & 0,30 \\
\hline $\begin{array}{c}\text { Całkowita liczba awarii sieci wodocią- } \\
\text { gowej }\end{array}$ & 84 & 54 & 51 & 55 & 56 \\
\hline Intensywność uszkodzeń $\lambda_{C}$ & 0,47 & 0,29 & 0,27 & 0,28 & 0,28 \\
\hline
\end{tabular}


Przeciętna wartość wskaźnika intensywności uszkodzeń $\lambda$ dla przewodów rozdzielczych $w$ analizowanym okresie pięciu lat (2008 - 2012) wynosi mniej niż $0,3 \mathrm{uszk} /(\mathrm{km} \cdot \mathrm{rok})$. Jedynie w 2008 wskaźnik ten wyniósł 0,54 uszk/(km·rok) i jest nieco wyższy od wartości uznawanej za kryterialną wynoszącą 0,5 uszk/(km·rok) dla tego rodzaju sieci [8]. W przypadku podłączeń wodociągowych średnia wartość tego wskaźnika wyniosła nieco ponad 0,3 uszk/(km·rok), ale i tak jest zdecydowanie niższa od wartości kryterialnych wynoszących 1 uszk/(km·rok) dla tego rodzaju sieci. Udokumentowana awaryjność sieci wodociągowej nie ma znaczącego wpływu na straty wody [8].

\section{Podsumowanie}

- W przeciągu ostatnich pięciu lat w Jaśle obserwujemy systematyczny spadek zapotrzebowania na wodę. Od 2008 roku z ponad 2374,67 tyś $\mathrm{m}^{3}$ zużycie wody zmalało do nieco ponad 2058, 47 tyś $\mathrm{m}^{3}$ w 2012 roku, co stanowi spadek zapotrzebowania na wodę o 13,32\%. Systematycznie od 2008 roku maleje ilość wody sprzedanej na cele produkcyjne, od 2008 roku dla gospodarstw domowych i od 2011 na pozostałe cele.

- Obecnie na całym świecie jednym z podstawowych problemów eksploatacyjnych wodociągów są straty wody. Faktem jest, że niekiedy stanowią one bardzo wysoki procent wody wtłaczanej do sieci. Analiza strat wody powinna być podstawą do podejmowania działań modernizacyjnych i naprawczych $\mathrm{w}$ celu ograniczenia kosztów związanych z produkcją wody i jej dystrybucją. Wycieki niezmiennie towarzyszą eksploatacji systemów zaopatrzenia w wodę. Podstawowym elementem oceny efektywności pracy, oraz stanu technicznego systemu wodociągu w aspekcie zużycia i strat wody jest jej prawidłowe zbilansowanie. Przeciwdziałanie wyciekom jest nieodzownym elementem każdego przedsiębiorstwa wodociągowego. Obecnie istnieje szereg metod pozwalających

w skuteczny i efektywny sposób wykrycia przecieków m.in.: metody związane $\mathrm{z}$ obserwacją tras przebiegu wodociągów, pomiarami ciśnienia, pomiarami przepływów, metody akustyczne i metoda rezystorowa.

- Jednostkowy wskaźnik strat wody w badanym okresie wyniósł około 30 $\mathrm{dm}^{3} / \mathrm{Mk} \cdot \mathrm{d}$. Średni jednostkowy wskaźnik wody wtłoczonej do sieci wynosi od $182,42 \mathrm{dm}^{3} / \mathrm{Mk} \cdot \mathrm{d}$ w $2008 \mathrm{roku}$ do $161,04 \mathrm{dm}^{3} / \mathrm{Mk} \cdot \mathrm{d}$ w $2011 \mathrm{roku}$. Natomiast jednostkowa ilość wody sprzedanej dla gospodarstw domowych wynosi ok. 80 $\mathrm{dm}^{3} / \mathrm{Mk} \cdot \mathrm{d}$.

- Infrastrukturalny wskaźnik wycieków ILI, który przyjmuje wartości od 5,84,3 wg WBI Banding System dla krajów rozwiniętych oceniany jest, jako słaby, natomiast dla krajów rozwijających się, jako dobry. Według Amerykańskiego Stowarzyszenia Wodnego (AWWA) stan sieci wodociągowej oceniany jest, jako dobry dla wartości mniejszych dla 5,0 lub słaby dla wartości większych od 
5,0. Bardzo rygorystyczne kryteria Międzynarodowego Stowarzyszenia Wodnego (IWA) odnoszące się do krajów wysokorozwiniętych wskazują na stan niedopuszczalny sieci. Przeciętne wartości infrastrukturalnego indeksu wycieków ILI w miastach Polski wynoszą od 3, 16 do 16, 62, z czego można wywnioskować, że Jasło jest na dość zadowalającej pozycji. Spadek wartości wskaźnika ILI, świadczy o skuteczności przyjętej strategii ograniczania przecieków wodociągowych w wodociągu Jasło.

- Intensywność uszkodzeń sieci wodociągowej Jasła mieści się w kryteriach europejskich i nie ma istotnego wpływu na starty wody. Analizy tej dokonano w oparciu o stwierdzone awarie na sieci wodociągowej (możliwe są nie ujawnione awarie).

\section{Literatura}

[1] Bergel T., Pawełek J.: Straty wody w systemach wodociaggowych- charakterystyka, wielkość, wykrywanie i ograniczanie. III Konferencja Naukowo- Techniczna Błękitny San - Dubiecko, 21-22 kwiecień 2006.

[2] Berger M., Ways M.: Poszukiwania przecieków sieci wodociągowych, Wydawnictwo Seidel-PrzyweckiSp.z o.o., Warszawa 2003.

[3] Dohnalik P.: Straty wody w miejskich sieciach wodociągowych, Wydawnictwo Polskiej Fundacji Ochrony Zasobów Wodnych, Bydgoszcz 2000.

[4] Dohnalik P., Jędrzejewski Z.: Efektywna eksploatacja wodociągów, Wydawnictwo LEMTECH Konsulting sp. z o.o., Kraków 2004.

[5] Hotloś H.: Analiza strat wody w systemach wodociągowych, Ochrona Środowiska, nr 1, 2003, s. 17-24.

[6] Lambert A.; Hibner W.:Losses from Water Supply Systems: Standard terminology and recommended performance measures; The BluPages, Copyright by IWA, no. $10 / 2000$.

[7] Pietrucha-Urbanik K., Studziński A.: Analiza strat wody wodociągu krośnieńskiego, Gaz, Woda i Technika Sanitarna, nr 10, 2012, s. 452-454.

[8] Rak J.R.: Zarządzanie ryzykiem w systemie zaopatrzenia w wodę, Oficyna Wyd. Politechniki Rzeszowskiej, Rzeszów 2009.

[9] Speruda S., Radecki R.: Ekonomiczny poziom wycieków, Wydawnictwo Translator s.c., Warszawa 2003.

[10] Sypień Ł.: Analiza zużycia i strat wody w wodociągu Jasła. Praca inżynierska PRz. Promotor J.R. Rak, Rzeszów 2012.

\section{ANALYSIS OF THE WATER LOSSES IN THE JASLO CITY}

\section{S u m m a r y}

Analysis of water losses should be the basis for the modernization act-ing in order to reduce the costs associated with the production of water and its distribution-tribution. The paper presents an analysis of water usage and losses in the waterworks in the Jasło city. The analysis was made on the basis of the data obtained from the Central Statistical Office and the Municipal Association 
of Jaslo. The results showed a trend of almost 15 percent reduction of water consumption by residents and business entities. During normal operation the balance of production and sales of tap water in 2008-2012. The basic indicators of water loss were established and referenced to the proposed indicators by the International Water Association. (IWA), as: percentage (WS), Infrastructure Leakage Index (RLB), the water volume-profit (MRWB), Unavoidable Annual Real Losses (UARL), infrastructure leakage index (ILI). Analyzed indicators are comparable to the values that have been obtained in other public water supply system in Poland. The obtained water failure indicators for each type of water supply point have negligible impact on water loss.

Keywords: water supply system, losses in water, water pipe failure

DOI: $10.7862 / \mathrm{rb} .2013 .33$

Przesłano do redakcji w lipcu $2013 \mathrm{r}$.

Przyjęto do druku we wrześniu 2013 r. 